\title{
PENGARUH GAYA KEPEMIMPINAN, MOTIVASI KOMUNIKASI, DAN BUDAYA ORGANISASIONAL TERHADAP DISIPLIN KERJA PEGAWAI KONTRAK
}

\author{
Cok Gede Bagus Sandi Rahadian ${ }^{1}$ \\ I Gusti Made Suwandana ${ }^{2}$
}

\author{
${ }^{\mathbf{1 , 2}}$ Fakultas Ekonomi dan Bisnis Universitas Udayana (Unud), Bali, Indonesia \\ e-mail: csrahadian@gmail.com
}

\begin{abstract}
ABSTRAK
Disiplin kerja ialah cara yang digunakan suatu instansi untuk mempengaruhi tingkah laku pegawainya agar taat terhadap ketentuan dan aturan dalam instansi. Agar pegawai memiliki disiplin kerja yang tinggi, suatu instansi perlu memperhatikan faktor-faktor yang mempengaruhi disiplin kerja. Tujuan penelitian ini adalah untuk mengetahui pengaruh gaya kepemimpinan, motivasi, komunikasi, dan budaya organisasional terhadap disiplin kerja pegawai kontrak Dinas Kebudayaan Provinsi Bali.Penelitian ini dilakukan di Dinas Kebudayaan Provinsi Bali. Jumlah sampel yang diambil sebanyak 53 orang pegawai kontrak, dengan metode sampling jenuh. Pengumpulan data dilakukan melalui wawancara dan kuisioner. Teknik analisis yang digunakan adalah regresi linier berganda.Berdasarkan hasil analisis ditemukan bahwa gaya kepemimpinan, motivasi, komunikasi, dan budaya organisasional berpengaruh signifikan terhadap disiplin kerja. Hal ini berarti semakin baik gaya kepemimpinan, motivasi, komunikasi, dan budaya organisasional yang diterapkan oleh instansi maka akan semakin tinggi pula tingkat disiplin kerja pegawai.

Kata kunci: disiplin kerja, gaya kepemimpinan, motivasi, komunikasi, budaya organisasional
\end{abstract}

\begin{abstract}
Work discipline is a method used by an agency to influence the behavior of its employees to comply with the provisions and rules in the agency. In order for employees to have high work discipline, an agency needs to pay attention to the factors that influence work discipline. The purpose of this study was to determine the effect of leadership style, motivation, communication, and organizational culture on the work discipline of employees of the Bali Province Cultural Service contract. This research was conducted at the Cultural Office of Bali Province. The number of samples taken was 53 contract employees, with a saturated sampling method. Data collection is done through interviews and questionnaires. The analysis technique used is multiple linear regression. Based on the results of the analysis it was found that leadership style, motivation, communication, and organizational culture had a significant effect on work discipline. This means that the better the leadership style, motivation, communication, and organizational culture applied by the agency, the higher the level of employee discipline.

Keywords: work discipline, leadership style, motivation, communication, organizational culture
\end{abstract}




\section{PENDAHULUAN}

Sumber daya manusia merupakan faktor terpenting yang mempengaruhi kemajuan suatu organisasi. Sumber daya manusia adalah salah satu aset berharga yang bisa menyelaraskan dengan perkembangan tersebut, karena dengan keahlian dan keterampilan manusialah operasional organisasi dapat berjalan sesuai yang diinginkan dan menciptakan persaingan kerja yang kompetitif.Sumber daya manusia memegang peran penting guna menghadapi perubahan yang terjadi serta merupakan harta atau aset yang paling penting dimiliki oleh suatu organisasi, karena keberhasilan organisasi sangat ditentukan oleh unsur manusia (Ardana, dkk., 2012: 3). Meningkatkan kualitassumberdaya manusia organisasi salah satunya instansi pemerintahharus memilikipengelolaanyangbaikterhadappegawainya.Pengelolaantersebut seharusnya didukungolehdisiplinpegawaidalammengimplementasikanaturanaturanmaupun program kerja yangtelahditetapkan oleh instansi.

Sumber daya manusia yang berkualitas memerlukan pembinaan disiplin kerja sebagai tindakan manajemen untuk mendorong para pegawainya untuk memenuhi berbagai ketentuan (Iswara dan Sudharma, 2013). Disiplin kerja menjadi salah satu faktor keberhasilan instansi pemerintah yang dapat dilihat dari tanggung jawab pegawai dalam ketepatan waktu kerja hingga hasil akhirnya (output). Kedisiplinan berperan sangat besar dalam menunjukkan tingkat kinerja pegawai untuk mencapai tujuan yang telah ditetapkan.

Seorang pemimpin memiliki peranan yang sangat penting dalam penegakan disiplin kerja (Suniastuti dan Suana, 2012). Pemimpin merupakan orang-orang 
yang memiliki keahlian atau kemampuan untuk dapat mempengaruhi orang lain agar dapat melakukan sesuatu sesuai dengan keinginannya dan tujuan yang ingin dicapai. Disiplin kerja tidak hanya dipengaruhi oleh satu faktor saja yaitu gaya kepemimpinan melainkan juga dipengaruhi oleh faktor lain salah satunya motivasi (Diantari dan Yuniari, 2014). Motivasi merupakan pendorong seseorang untuk melakukan pekerjaannya dengan baik. Seseorang yang termotivasi akan membuat sebuah pilihan positif untuk melakukan sesuatu karena dapat memuaskan keinginannya. Motivasi dapat memacu seorang pegawai untuk bekerja keras dalam rangka pencapaian tujuan. Rivai (2009: 837), menyatakan bahwa motivasi merupakan kumpulan rangkaian sikap dan nilai yang dimiliki seseorang yang mempengaruhi perilaku dan tingkah lakunya untuk mencapai tujuan yang spesifik.

Faktor yang mempengaruhi disiplin kerja selain motivasi adalah komunikasi (Suaip dan Astuti, 2015). Komunikasi adalah sarana berinteraksi diantara pegawai dan pimpinan suatu organisasi. Komunikasi yang kurang baik dalam suatu organisasi dapat menghambat kemajuan organisasi itu sendiri. Disiplin kerja pegawai juga dapat dipengaruhi oleh budaya organisasional yang dianut oleh instansi. Budaya organisasional merupakan nilai-nilai, prinsip, tradisi dan caracara bekerja yang dianut bersama oleh para anggota organisasi dan memengaruhi cara mereka bertindak (Robbins, 2010). Budaya organisasional memberikan identitas pada anggotanya untuk berperilaku sesuai prinsip dan nilai organisasi. Perilaku yang dikatakan sejalan dengan prinsip dan nilai organisasi, apabila prinsip dan nilai tersebut dapat dimaknai dan dipahami oleh anggota organisasi 
dengan baik dan benar. Prinsip-prinsip dan nilai organisasi seperti diuraikan tersebut, akan berlaku bagi setiap organisasi baik itu organisasi/instansi pemerintah maupun swasta.

Dinas Kebudayaan ProvinsiBaliadalah salah satu instansipemerintahyang memberikanpelayanankepadamasyarakat. Dinas Kebudayaan Provinsi Bali membidangitentang kebudayaan dan kesenian daerah yang sudah dikenal di mancanegara. Kebudayaan dan kesenian daerah Bali merupakan salah satu faktor pendukung utama provinsi Bali sebagai daerah tujuan pariwisata. Kondisi tersebut mengindikasikan bahwa kemajuan pariwisata Bali tidak bisa terlepas dari masalah kedisiplinan pada setiap individu, termasuk seluruh aparatur pada Dinas Kebudayaan Provinsi Bali. Disiplin kerja pegawai yang tinggi sangat membantu pencapaian tujuan instansi pemerintah dan tidak terkecuali Dinas Kebudayaan Provinsi Bali. Pegawai pada Dinas Kebudayaan Provinsi Bali dilihat dari sisi statusnya dikelompokkan menjadi dua jenis, yaitu: Aparatur Sipil Negara (ASN) dan pegawai kontrak. Pegawai kontrak yang dimaksud adalah pegawai yang direkrut oleh Dinas Kebudayaan Provinsi Bali untuk membantu kelancaran pelaksanaan tugas. Pegawai kontrak tersebut dipekerjakan sesuai dengan kebutuhan selama satu tahun dan dapat diperpanjang apabila diperlukan.

Hasil wawancara awal terhadap 10 orang pegawai kontrak Dinas Kebudayaan Provinsi Bali, tergambar bahwa kedisiplinan kerja pegawai khususnya pegawai kontrak dinilai masih kurang memuaskan sebagaimana layaknya kedisiplinan pegawai kontrak secara umum. Hal tersebut tercermin dari sering terlambat datang ke kantor, tidak hadir tanpa alasan yang jelas, waktu 
istirahat yang dilakukan secara bersamaan, pulang kerja sebelum waktunya, serta pemahaman terhadap tugas yang dibebankan masih kurang jelas. Keadaaan tersebut dinilai agar mengingat status dan kemungkinan pengembangan karir pegawai kontrak jauh berbeda dengan Aparatur Sipil Negara (ASN). Dampak yang mungkin bisa ditimbulkan dari status tersebut salah satunya adalah tingginya tingkat absensi.

Tabel 1.

Tingkat Absensi Pegawai Kontrak Dinas Kebudayaan Provinsi Bali

\begin{tabular}{|c|c|c|c|c|c|c|}
\hline $\begin{array}{l}\text { Bulan } \\
\text { (1) }\end{array}$ & $\begin{array}{l}\text { Jumlah } \\
\text { Pegawai } \\
\text { Kontrak } \\
\text { (2) }\end{array}$ & $\begin{array}{l}\text { Jumlah } \\
\text { Hari } \\
\text { Kerja } \\
\text { (3) }\end{array}$ & $\begin{array}{l}\text { Jumlah } \\
\text { Hari } \\
\text { Kerja/ } \\
\text { Bulan } \\
\text { (4) }\end{array}$ & $\begin{array}{l}\text { Total } \\
\text { Absensi } \\
\text { (Tanpa } \\
\text { Keterangan) } \\
(5)\end{array}$ & $\begin{array}{l}\text { Jumlah } \\
\text { Hari } \\
\text { Kerja } \\
\text { Efektif } \\
(6)\end{array}$ & $\begin{array}{l}\text { Persentase } \\
(\%)= \\
(5) /(4) \times \\
100 \%\end{array}$ \\
\hline Januari & 53 & 19 & 1007 & 42 & 965 & 4,17 \\
\hline Februari & 53 & 19 & 1007 & 38 & 969 & 3,77 \\
\hline Maret & 53 & 21 & 1113 & 38 & 1075 & 3,41 \\
\hline April & 53 & 21 & 1113 & 45 & 1068 & 4,04 \\
\hline Mei & 53 & 18 & 954 & 38 & 916 & 3,98 \\
\hline Juni & 53 & 21 & 1113 & 43 & 1070 & 3,86 \\
\hline Juli & 53 & 16 & 848 & 41 & 807 & 4,83 \\
\hline Agustus & 53 & 21 & 1113 & 38 & 1075 & 3,41 \\
\hline Jumlah & & 156 & 8268 & 323 & 7945 & 31,47 \\
\hline Rata-Rata & & & & & & 3,93 \\
\hline
\end{tabular}

Sumber: Dinas Kebudayaan Provinsi Bali, 2018

Berdasarkan Tabel 1 tergambar bahwa rata-rata tingkat absensi pegawai kontrak Dinas Kebudayaan Provinsi Bali bulan Januari sampai dengan bulan Agustus 2018 yaitu persentase 3,93. Absensi 0 sampai dengan 2 persen dinyatakan baik, sedangkan absensi diatas 3 persen menunjukkan rendahnya disiplin kerja pegawai (Flippo, 2001: 281). Kemangkiran pegawai tanpa alasan merupakan keadaan yang merugikan instansi. Rata-rata absensi diatas 3 persen merupakan tingkat absensi yang dinyatakan tinggi dan salah satu indikasi adanya masalah yang terjadi di tingkat kedisiplinan pegawai (Jaya dan Adnyani, 2015). Data diatas mencerminkan bahwa masalah kedisiplinan khususnya pada pegawai 
kontrak Dinas Kebudayaan Provinsi Bali masih perlu mendapat perhatian dan menemukan solusi tentang faktor-faktor penyebabnya. Situasi ini apabila tidak dikelola dengan baik akan menghambat kemajuan Dinas Kebudayaan Provinsi Bali. Berdasarkan uraian tersebut, maka penelitian ini penting dilakukan untuk membuktikan secara empiris tentang disiplin kerja pegawai pada Dinas Kebudayaan Provinsi Bali dikaitkan dengan gaya kepemimpinan, motivasi, komunikasi, dan budaya organisasional.

Organisasi harus melakukan pengawasan guna mengontrol disiplin kerja pegawai sehari-hari, karena tingkat disiplin kerja akan berdampak positif pada pencapaian tujuan organisasi tersebut (Permata dan Mujiati, 2017). Tujuan utama disiplin adalah untuk meningkatkan efisiensi semaksimal mungkin untuk mencegah pemborosan waktu dan energi (Sutrisno, 2009: 92). Sutrisno (2009: 95) menyatakan bahwa salah satu faktor yang dapat mempengaruhi kedisiplinan adalah adanya peraturan yang ditetapkan organisasi. Salah satu contoh peraturan tersebut adalah peraturan jam masuk, jam pulang dan jam istirahat.

Disiplin yang baik mencerminkan besarnya tanggung jawab pegawai terhadap tugas-tugas yang diberikan. Disiplin lebih banyak bersumber dari dalam diri pegawai itu sendiri yang diperlihatkan dalam bentuk mematuhi peraturan yang ada di dalam instansi dan menyelesaikan tugas tepat waktu. Untuk memelihara dan menegakkan disiplin yang baik ada banyak yang mempengaruhinya.

Keberhasilan seorang manajer atau pemimpin dalam memimpin orang dinilai dari kinerja dan hasil tim (Mohelska, 2015). Pemimpin sangat berperan 
dalam menentukan keberhasilan suatu instansi, instansi dikatakan berhasil apabila mampu meningkatkan peran serta aktif dari pegawai. Gaya kepemimpinan sangat di perlukan di dalam suatu instansi karena dengan adanya gaya kepemimpinan tersebut pimpinan bisa melakukan suatu inovasi-inovasi dan dapat mengkoordinir semua fungsi instansi dengan baik dan benar. Terlebih pegawai yang baik ingin mengetahui bagaimana cara mereka untuk dapat menyumbang dalam pencapaian tujuan peruahaan. Oleh karena itu gaya kepemimpinan yang dimiliki oleh seorang manajer hendaknya dapat menciptakan integrasi tinggi dan mendorong gairah kerja pegawai itu sendiri.

Ardana (2012: 193) menyatakan motivasi merupakan kekuatan yang mendorong seseorang untuk melakukan suatu tindakan pada hakekatnya yakni secara ekternal dan internal atau secara positif atau negatif dan untuk mengarahkannya sangat bergantung kepada manajer atau pimpinannya. Motivasi kerja yang tinggi akan berdampak pada disiplin pegawai yang tinggi pula (Hakim, 2011). Lin (2009) dalam penelitiannya menyebutkan motivasi kerja seseorang dapat timbul melalui faktor strategi sumber daya manusia yang dimiliki instansi. Motivasi merupakan suatu hal tidak berwujud, bahkan motivasi seseorang susah diamati secara jelas, Luthans (2006: 125) menyatakan motivasi merupakan proses berbagai langkah awal yang dilakukan oleh seseorang atau individu dalam melakukan tindakan akibat kekurangan secara fisik dan psikis atau dengan kata lain adalah suatu dorongan yang ditunjukkan untuk memenuhi tujuan tertentu. 
Ephraim (2012) menyatakan bahwa disiplin yang baik dibentuk atau dihasilkan dari komunikasi yang baik dari seseorang. Fatma (2008), menyatakan bahwa komunikasi yang efektif itu sangat penting pada semua tingkatan/level dalam organisasi untuk menghasilkan pemahaman yang sama antara pengirim dan penerima informasi sehingga menciptakan efektivitas organisasi. Komunikasi yang berjalan dengan baik dan efektif akan membantu dalam memotivasi pegawai agar lebih semangat dalam mengerjakan tugas-tugas yang dilimpahkan padanya (Raymond Ross, 2010).

Pegawai dan pimpinan dapat berinteraksi dengan baik dalam memecahkan suatu permasalahan yang ada di dalam suatu instansi atau organisasi yang dapat menghambat kemajuan instansi itu sendiri. Komunikasi baik antara pimpinan dengan pegawai maupun antar sesama pegawai merupakan salah satu faktor penting untuk meningkatkan disiplin kerja pegawai. Salah satu bentuk kekurangan komunikasi adalah sedikitnya waktu yang digunakan pimpinan untuk berdiskusi dengan bawahan dalam hal pekerjaan sangat mempengaruhi disiplin kerja pegawai. Pimpinan dan pegawai hanya mampu berinteraksi dalam suasana yang formal saja sehingga belum mampu menciptakan keakraban antara dua belah pihak sehingga berdampak kepada tingkat disiplin pegawai terhadap instansi. Suasana formal yang dimaksud adalah suasana dalam rapat. Komunikasi secara intensif antara pimpinan dengan bawahan hanya terjadi saat rapat. Permasalahan yang dihadapi instansi maupun pegawai instansi yang terkait dengan kinerjanya hanya dapat disampaikan saat rapat. Waktu pelaksanaan rapat 
yang seringkali sangat singkat sehingga berdampak pada penyelesaian masalah yang tidak maksimal.

Robbins dan Judge (2010), menyatakan bahwa budaya organisasional adalah sistem makna bersama yang dianut oleh anggota-anggota yang membedakan organisasi itu dari organsisasi-organisasi lain. Sedangkan Moorhead (1995: 246), menyatakan bahwa budaya organisasi diartikan sebagai, seperangkat nilai yang diterima selalu benar, yang membantu seseorang dalam organisasi untuk memahami tindakan-tindakan mana yang dapat diterima dan tindakan mana yang tidak dapat diterima dan nilai-nilai tersebut dikomunikasikan melalui cerita dan cara-cara simbolis lainnya. Berdasarkan definisi diatas dapat disimpulkan bahwa budaya organisasional sesungguhnya tumbuh karena diciptakan dan dikembangkan oleh individu yang bekerja dalam suatu organisasi, dan diterima sebagai nilai-nilai yang harus dipertahankan dan diturunkan kepada setiap anggota baru.

Robbins (2010) menjelaskan budaya organisasional merupakan nilai-nilai, prinsip, tradisi dan cara-cara bekerja yang dianut bersama oleh para anggota organisasi dan memengaruhi cara mereka bertindak. Budaya organisasional terdiri dari nilai-nilai dominan yang didukung oleh organisasi atau falsafah yang menuntun kebijaksanaan organisasi terhadap pegawai dan pelanggaran, atau cara pekerjaan yang dilakukan di tempat kerja, serta asumsi maupun kepercayaan yang terdapat pada anggota organisasi.

Beverly et al. (2008) dalam penelitiannya menjelaskan bahwa keterlibatan pemimpin dalam beraktifitas dapat meningkatkan aturan standar kerja (dapat 
dikatakan sebagai disiplin kerja). Bimbingan kepemimpinan akan mampu meningkatkan tujuan organisasi dan untuk meningkatkan disiplin kerja pegawai (Mahdi et al., 2014). Ondari et al. (2016) menyatakan bahwa tingkat disiplin dipengaruhi oleh gaya kepemimpinan yang diterapkan oleh organisasi.

Penelitian Suniastuti dan Suana (2012), menyatakan bahwa gaya kepemimpinan berpengaruh terhadap disiplin kerja. Hal ini menunjukkan bahwa pemimpin yang tegas dalam melaksanakan aturan yang berlaku dan pemimpin adil dalam pemberian sanksi kepada karyawan yang melanggar dengan adanya hal ini akan dapat mendorong rasa kedisiplinan kerja karyawan untuk mencapai prestasi yang di inginkan. Iswara dan Sudharma (2013), menyatakan bahwa gaya kepemimpinan mampu membentuk disiplin kerja yang mendasar melalui jalinan kerjasama. Jaya dan Adnyani (2015), menyatakan bahwa gaya kepemimpinan berpengaruh positif terhadap disiplin kerja. Permata dan Mujiati (2017) menemukan bahwa gaya kepemimpinan berpengaruh positif dan signifikan terhadap disiplin kerja. Hal ini berarti semakin baik gaya kepemimpinan yang diterapkan dalam suatu instansi atau organisasi, maka akan semakin tinggi pula tingkat kedisiplinan pegawainya. Rumusan hipotesis berdasarkan teori dan penelitian terdahulu adalah sebagai berikut.

$\mathrm{H}_{1}$ : Gaya kepemimpinan berpengaruh positif dan signifikan terhadap disiplin kerja.

Chowdhury (2010), menyatakan bahwa motivasi merupakan faktor yang mempengaruhi disiplin karyawan. Sugiyatmi, dkk. (2012), menyatakan bahwa semakin tinggi motivasi kerja karyawan maka semakin tinggi pula tingkat 
kedisiplinan karyawan tersebut. Hasil ini selaras dengan penelitian Bangsawan (2012), yang menyatakan bahwa bahwa salah satu faktor yang memiliki pengaruh positif terhadap disiplin kerja pegawai adalah motivasi. Penelitian Diantari dan Yuniari (2014), menyatakan bahwa motivasi berpengaruh positif dan signifikan terhadap disiplin kerja. Hal ini berarti semakin tinggi motivasi maka semakin tinggi pula disiplin kerja yang dimiliki oleh pegawai tersebut. Dessy dan Wibawa (2015), menyatakan bahwa motivasi berperan penting dalam meningkatkan disiplin kerja pegawai pada instansi. Rumusan hipotesis berdasarkan teori dan penelitian terdahulu adalah sebagai berikut.

$\mathrm{H}_{2}$ : Motivasi berpengaruh positif dan signifikan terhadap disiplin kerja.

Penelitian Suaip dan Astuti (2015) menyatakan bahwa komunikasi berpengaruh signifikan terhadap disiplin kerja. Hal ini berarti semakin baik komunikasi dalam suatu instansi maka akan meningkatkan disiplin kerja pegawainya. Suniastuti dan Suana (2012), menyatakan bahwa motivasi berpengaruh positif terhadap disiplin kerja pegawai. Hal ini berarti semakin baik komunikasi yang diterapkan antara pimpinan dengan bawahan maupun antar sesama rekan sekerja maka akan semakin disiplin pula pegawai tersebut. Dessy dan I Made Artha Wibawa (2015) menyatakan bahwa motivasi berperan penting dalam meningkatkan disiplin kerja pegawai pada instansi. Azis dan Muchtar (2016) menyatakan bahwa komunikasi memiliki pengaruh langsung terhadap disiplin kerja, semakin baik komunikasi dalam instansi maka akan meningkatkan disiplin kerja karyawannya. Rahmadhani dan Iskandar (2016) menyatakan bahwa komunikasi merupakan salah satu faktor yang dapat mempengaruhi disiplin kerja 
karyawan. Semakin baik komunikasi antara pimpinan dengan karyawan maupun komunikasi antara sesama rekan sekerja akan dapat meningkatkan disiplin kerja karyawan. Rumusan hipotesis berdasarkan teori dan penelitian terdahulu adalah sebagai berikut.

$\mathrm{H}_{3}$ : Komunikasi berpengaruh positif dan signifikan terhadap disiplin kerja.

Damayanti dan Mahendra (2014) menyatakan bahwa budaya organisasional sangat mempengaruhi perilaku pegawai, budaya organisasional yang kuat akan berpengaruh terhadap pembentukan perilaku anggota-anggotanya, yang kemudian akan menjadikan budaya dalam suatu organisasi tersebut. Suniastuti dan Suana (2012) menyatakan bahwa adanya budaya yang mengatur tingkah laku karyawan seperti jam masuk kantor yang telah disesuaikan oleh instansi akan dapat meningkatkan kedisiplinan kerja karyawan. Penelitian Iswara dan Sudharma (2013), juga menemukan bahwa budaya organisasional berpengaruh positif dan signifikan terhadap disiplin kerja. Hal ini berarti semakin kuat budaya organisasional suatu instansi atau organisasi maka semakin tinggi pula tingkat kedisiplinan pegawai tersebut. Hady, Hamdy et al. menyatakan bahwa budaya organisasional berpengaruh positif dan signifikan terhadap disiplin kerja karyawan. Hal ini berarti semakin kuat budaya organisasi dalam instansi maka semakin tinggi tingkat disiplin pegawainya. Oktaviani dan Saragih (2017) menyatakan bahwa budaya organisasional berpengaruh positif dan signifikan terhadap disiplin kerja karyawan. Marhendro (2016) menyatakan bahwa budaya organisasi menjadi faktor yang mempengaruhi disiplin kerja pegawai yang berasal dari luar. Budaya organisasi yang kuat akan memaksa dan mempengaruhi 
anggotanya untuk melakukan sesuatu yang diperintahkan atau yang menjadi kebiasaan didalam organisasi tersebut. Rumusan hipotesis berdasarkan teori dan penelitian terdahulu adalah sebagai berikut.

$\mathrm{H}_{4}$ : Budaya organisasional berpengaruh positif dan signifikan terhadap disiplin kerja.

\section{METODE PENELITIAN}

Lokasi penelitian ini adalah pada Dinas Kebudayaan Provinsi Bali yang berlokasi di JalanIr. Djuanda No.1CivicCenterNitiMandalaRenon, Denpasar. Lokasi ini dipilih karena ditemukan masalah-masalah yang terkait dengan gaya kepemimpinan, motivasi, komunikasi, dan budaya organisasional yang berpengaruh terhadap disiplin kerja pegawai kontrak Dinas Kebudayaan Provinsi Bali. Objek penelitian ini adalah masalah kedisiplinan kerja yang dikaitkan dengan gaya kepemimpinan, motivasi, komunikasi, budaya organisasional pegawai kontrak Dinas Kebudayaan Provinsi Bali.

Populasi yang digunakan dalam penelitian ini adalah seluruh pegawai kontrak pada Dinas Kebudayaan Provinsi Bali yang berjumlah 53 pegawai yang semuanya dijadikan sebagai responden (sampel jenuh). Teknik ini dipilih karena jumlah dari populasi tergolong kecil, sehingga seluruh populasi digunakan sebagai sampel dalam penelitian ini.

Analisis regresi linier berganda digunakan untuk mengetahui seberapa besar pengaruh variabel bebas yaitu Gaya Kepemimpinan $\left(\mathrm{X}_{1}\right)$, Motivasi $\left(\mathrm{X}_{2}\right)$, Komunikasi $\left(\mathrm{X}_{3}\right)$, dan Budaya Organisasional $\left(\mathrm{X}_{4}\right)$ terhadap variabel terikatnya yaitu Disiplin Kerja (Y). 
E-Jurnal Manajemen, Vol. 8, No. 6, $2019: 3590-3617$

Bentuk persamaan regresi linier berganda adalah sebagai berikut:

$$
Y=a+b_{1} \cdot X_{1}+b_{2} . X_{2}+b_{3} . X_{3}+b_{4} \cdot X_{4} .
$$

\section{Keterangan:}

Y

a

$b_{1}, b_{2}, b_{3}, b_{4}$

$\mathrm{X}_{1}, \mathrm{X}_{2}, \mathrm{X}_{3}, \mathrm{X}_{4}$
$=$ Variabel Terikat $($ Disiplin Kerja $)$

$=$ Konstanta

= Koefisien Garis Regresi

=Variabel Bebas (Gaya Kepemimpinan, Motivasi,

Komunikasi, dan Budaya Organisasional). 


\section{HASIL DAN PEMBAHASAN}

Responden dalam penelitian ini menunjukkan persentase responden laki-laki sebesar 64,1 persen dan responden perempuan sebesar 35,9 persen. Hal ini menunjukkan bahwa responden laki-laki lebih banyak dibandingkan dengan perempuan. Jumlah laki-laki lebih banyak dikarenakan laki-laki memiliki pola pikir yang cenderung didasarkan pada fakta, sedangkan perempuan cenderung pada konsep dan jalinan hubungan. Selain itu laki-laki cenderung lebih tegas dibanding perempuan, serta dapat bekerja sama dengan baik dibandingkan perempuan, sehingga sesuai dengan kebutuhan untuk mencapai tujuan Dinas Kebudayaan Provinsi Bali.

Kelompok usia dominan adalah pada usia 20-30 tahun dengan persentase 56,6 persen, sedangkan untuk kelompok usia yang terendah adalah pada usia 4150 tahun dengan persentase 15,1 persen. Kelompok usia 20-30 tahun merupakan usia produktif sehingga sesuai dengan kebutuhan Dinas Kebudayaan Provinsi Bali.

Responden yang dominan berdasarkan jabatan adalah pada jabatan administrasi dengan persentase 83,0 persen, sedangkan yang terendah adalah pada jabatan penjaga keamanan dengan persentase 7,6 persen. Hal ini menunjukkan bahwa Dinas Kebudayaan Provinsi Bali membutuhkan jumlah pegawai kontrak pada jabatan administrasi yang lebih tinggi dibandingkan jabatan lainnya.

Responden yang dominan berdasarkan pendidikan adalah pada tingkat pendidikan S1 dengan persentase 86,8 persen, sedangkan yang terendah adalah pada tingkat pendidikan D3 dengan persentase 13,2 persen. Hal ini menunjukkan 
bahwa Dinas Kebudayaan Provinsi Bali membutuhkan pegawai yang memiliki skill, pendidikan, dan keahlian di bidangnya.

Responden yang dominan berdasarkan masa kerja adalah masa kerja selama 3-5 tahun dengan persentase 41,5 persen, sedangkan yang terendah adalah pada masa kerja selama kurang dari 1 tahun dengan persentase 3,8 persen. Hal ini menunjukkan bahwa Dinas Kebudayaan Provinsi Bali diisi oleh sumber daya manusia yang berpengalaman.

Hasi uji validitas instrumen penelitian akan disajikan pada tabel 2.

Tabel 2.

Hasil Uji Validitas

\begin{tabular}{|c|c|c|c|c|}
\hline No & Variabel & Item Pernyataan & $\begin{array}{c}\text { Korelasi Item } \\
\text { Total }\end{array}$ & Keterangan \\
\hline \multirow{4}{*}{1} & \multirow{4}{*}{ Disiplin Kerja (Y) } & $\mathrm{Y}_{1}$ & 0,684 & Valid \\
\hline & & $Y_{2}$ & 0,735 & Valid \\
\hline & & $\mathrm{Y}_{3}$ & 0,747 & Valid \\
\hline & & $\mathrm{Y}_{4}$ & 0,623 & Valid \\
\hline \multirow{5}{*}{2} & \multirow{5}{*}{ Gaya Kepemimpinan $\left(\mathrm{X}_{1}\right)$} & $\mathrm{X}_{1.1}$ & 0,750 & Valid \\
\hline & & $X_{1.2}$ & 0,828 & Valid \\
\hline & & $\mathrm{X}_{1.3}$ & 0,847 & Valid \\
\hline & & $\mathrm{X}_{1.4}$ & 0,786 & Valid \\
\hline & & $\mathrm{X}_{1.5}$ & 0,836 & Valid \\
\hline \multirow{4}{*}{3} & \multirow{4}{*}{ Motivasi $\left(\mathrm{X}_{2}\right)$} & $\mathrm{X}_{2.1}$ & 0,557 & Valid \\
\hline & & $\mathrm{X}_{2.2}$ & 0,812 & Valid \\
\hline & & $\mathrm{X}_{2.3}$ & 0,708 & Valid \\
\hline & & $\mathrm{X}_{3.1}$ & 0,849 & Valid \\
\hline \multirow[t]{3}{*}{4} & \multirow{2}{*}{ Komunikasi $\left(\mathrm{X}_{3}\right)$} & $\mathrm{X}_{3.2}$ & 0,908 & Valid \\
\hline & & $\mathrm{X}_{3.3}$ & 0,785 & Valid \\
\hline & \multirow{5}{*}{$\begin{array}{l}\text { Budaya Organisasional } \\
\qquad\left(\mathrm{X}_{4}\right)\end{array}$} & $\mathrm{X}_{4.1}$ & 0,752 & Valid \\
\hline \multirow{4}{*}{5} & & $X_{4.2}$ & 0,777 & Valid \\
\hline & & $\mathrm{X}_{4.3}$ & 0,805 & Valid \\
\hline & & $\mathrm{X}_{4.4}$ & 0,763 & Valid \\
\hline & & $\mathrm{X}_{4.5}$ & 0,730 & Valid \\
\hline
\end{tabular}

Sumber: Data diolah, 2018

Hasil uji validitas pada tabel 3 menunjukan bahwa semua variabel memiliki koefisien korelasi dengan skor total seluruh item pertanyaan lebih besar dari 0,30. Hal ini menunjukan bahwa butir-butir pernyataan dalam instrumen penelitian tersebut valid. 
Hasil pengujian reliabilitas instrumen dapat dilihat pada tabel 3.

Tabel 3.

Hasil Uji Reliabilitas

\begin{tabular}{clcc}
\hline No & \multicolumn{1}{c}{ Variabel } & Cronbach's Alpha & Keterangan \\
\hline 1 & Disiplin Kerja $(\mathrm{Y})$ & 0,938 & Reliabel \\
2 & Gaya Kepemimpinan $\left(\mathrm{X}_{1}\right)$ & 0,927 & Reliabel \\
3 & Motivasi $\left(\mathrm{X}_{2}\right)$ & 0,818 & Reliabel \\
4 & Komunikasi $\left(\mathrm{X}_{3}\right)$ & 0,924 & Reliabel \\
5 & Budaya Organisasional $\left(\mathrm{X}_{4}\right)$ & 0,906 & Reliabel \\
\hline \multicolumn{2}{l}{ Sumber: Data diolah, 2018 }
\end{tabular}

Hasil uji reliabilitas yang disajikan dalam tabel menunjukan bahwa setiap variabel memiliki nilai koefisien Alpha Cronbach lebih dari 0,60. Hal ini dapat dikatakan bahwa variabel disiplin kerja, gaya kepemimpinan, motivasi, komunikasi, dan budaya organisasional adalah reliabel.

Uji normalitas dilakukan untuk menguji apakah pada residual dari model regresi yang telah dibuat berdistribusi normal atau tidak. Model regresi yang baik merupakan model yang memiliki distribusi residual yang normal atau mendekati normal. Untuk menguji normalitas residual digunakan uji statistik non-parametrik Kolmogorov-Smirnov $(K-S)$. Kriteria yang digunakan uji ini adalah dengan membandingkan antara tingkat signifikansi yang didapat dengan tingkat alpha yang digunakan yaitu 5\% (0,05). Jika nilai signifikansinya lebih besar dari alpha 0,05 maka distribusi data dinyatakan memenuhi asumsi normalitas.

Tabel 4.

Hasil Uji Normalitas

\begin{tabular}{lccc}
\hline & Statistik & Df & Sig \\
\hline $\begin{array}{l}\text { Unstandardized } \\
\text { Residual }\end{array}$ & 0.070 & 53 & $.200^{*}$ \\
\hline Sumber: Data diolah, 2018 & & &
\end{tabular}

Berdasarkan Tabel 4 dapat dilihat bahwa nilai signifikan adalah sebesar 0,200. Hasil tersebut mengindikasikan bahwa model persamaan regresi tersebut 
berdistribusi normal karena nilai signifikan sebesar 0,200 lebih besar dari nilai alpha 0,05 .

Uji multikolonearitas dapat diketahui dari nilai tolerance dan variance inflation factor (VIF). Nilai cut off yang digunakan untuk menunjukkan adanya multikolonearitas adalah apabila nilai tolerance $<0,10$ dan nilai VIF $>10$.

Tabel 5. Hasil Uji Multikolinearitas

\begin{tabular}{ccc}
\hline Variabel & Tolerance & VIF \\
\hline Gaya Kepemimpinan & 0,448 & 2,232 \\
Motivasi & 0,722 & 1,384 \\
Komunikasi & 0,423 & 2,363 \\
Budaya Organisasional & 0,969 & 1.032 \\
\hline Sumber: Data diolah, 2018 & &
\end{tabular}

Berdasarkan hasil output di atas, hasil perhitungan nilai Tolerance menunjukkan tidak ada variabel bebas gaya kepemimpinan, motivasi, komunikasi, dan budaya organisasional yang memiliki nilai Tolerance $<0,10$. Dan jika dilihat dari nilai Variance Inflantion Factor (VIF) menunjukkan hasil yang sama, yaitu tidak ada variabel bebas gaya kepemimpinan, motivasi, komunikasi, dan budaya organisasional yang memiliki nilai $V I F>10$. Jadi dapat disimpulkan bahwa tidak terjadi multikolinearitas antar variabel bebas.

Uji ini bertujuan untuk mengetahui apakah dalam model terjadi ketidaksamaan varian dari residual satu pengamatan ke pengamatan lain yang dilakukan dengan uji Glejser. Model dikatakan tidak mengandung gejala heteroskedastisitas jika tabel coefficients menghasilkan nilai signifikansi lebih besar dari alpha 0,05 . 
Tabel 6.

Hasil Uji Heteroskedastisitas

\begin{tabular}{|c|c|c|c|c|c|}
\hline \multirow[t]{2}{*}{ Model } & \multicolumn{2}{|c|}{$\begin{array}{l}\text { Unstandardized } \\
\text { Coefficients }\end{array}$} & \multirow{2}{*}{$\begin{array}{c}\text { Standardized } \\
\text { Coefficients } \\
\text { Beta }\end{array}$} & \multirow[t]{2}{*}{$\mathbf{T}$} & \multirow[t]{2}{*}{ Sig. } \\
\hline & B & Std. Error & & & \\
\hline (Constant) & 0.551 & 1.377 & & 0.400 & 0.691 \\
\hline Gaya Kepemimpinan & 0.079 & 0.041 & 0.389 & 1.903 & 0.063 \\
\hline Motivasi & -0.083 & 0.086 & -0.155 & -0.959 & 0.342 \\
\hline Komunikasi & -0.096 & 0.077 & -0.263 & -1.249 & 0.218 \\
\hline Budaya Organisasional & 0.053 & 0.048 & 0.154 & 1.106 & 0.274 \\
\hline
\end{tabular}

Sumber: Data diolah, 2018

Berdasarkan Tabel 6 dapat dilihat bahwa nilai signifikansi dari variabel gaya kepemimpinan adalah sebesar 0,063 , motivasi sebesar 0,342, komunikasi sebesar 0,218, dan budaya organisasional sebesar 0,274. Seluruh nilai masingmasing variabel tersebut lebih besar dari alpha 0,05 yang berarti bahwa model yang dibuat tidak mengandung gejala heteroskedastisitas.

Adapun hasil analisis regresi dengan menggunakan program SPSS versi 25 dapat dilihat pada Tabel 7.

Tabel 7.

Hasil Analisis Regresi Linear Berganda

\begin{tabular}{|c|c|c|c|c|}
\hline \multirow{2}{*}{ Variabel } & \multicolumn{2}{|c|}{ Koefisien Regresi } & \multirow{2}{*}{$\mathbf{T}$} & \multirow{2}{*}{ Sig } \\
\hline & B & Std. Error & & \\
\hline (constant) & & 2.330 & -0.844 & 0.403 \\
\hline Gaya Kepemimpinan $\left(\mathrm{X}_{1}\right)$ & 0.466 & 0.070 & 4.280 & 0.000 \\
\hline Motivasi $\left(\mathrm{X}_{2}\right)$ & 0.234 & 0.146 & 2.728 & 0.009 \\
\hline Komunikasi $\left(\mathrm{X}_{3}\right)$ & 0.267 & 0.130 & 2.387 & 0.021 \\
\hline Budaya Organisasional $\left(\mathrm{X}_{4}\right)$ & 0.165 & 0.082 & 2.231 & 0.030 \\
\hline
\end{tabular}

Sumber: Data diolah, 2018

Berdasarkan Tabel 7 dapat ditulis persamaan regresi linear berganda sebagai berikut.

$$
Y=0,466 \cdot X_{1}+0,234 \cdot X_{2}+0,267 \cdot X_{3}+0,165 \cdot X_{4}
$$

Dimana:

$\mathrm{b}_{1}, \mathrm{~b}_{2}, \mathrm{~b}_{3}, \mathrm{~b}_{4}=$ Koefisien Garis Regresi

$\mathrm{Y}=$ Variabel Terikat (Disiplin Kerja) 
$\mathrm{X}_{1}, \mathrm{X}_{2}, \mathrm{X}_{3}, \mathrm{X}_{4}=$ Variabel Bebas (Gaya Kepemimpinan, Motivasi, Komunikasi, dan Budaya Organisasional)

Nilai Adjusted $R^{2}$ yang kecil berarti bahwa kemampuan dari variabelvariabel bebas dalam menjelaskan keragaman variabel terikat sangat rendah, sednagkan jika nilai koefisien determinasi (Adjusted $R^{2}$ ) mendekati satu berarti variabel-variabel bebas hampir memberikan semua informasi yang dibutuhkan untuk menduga keragaman variabel terikat.

Tabel 8.

Hasil Uji Koefisien Determinasi $\left(\mathbf{R}^{2}\right)$

\begin{tabular}{llllrrl}
\hline Model & R & R Square & $\begin{array}{l}\text { Adjusted } \\
\text { Square }\end{array}$ & $\begin{array}{l}\text { Rtd. Error of } \\
\text { The Estimate }\end{array}$ & $\begin{array}{l}\text { Durbin- } \\
\text { Watson }\end{array}$ \\
\hline 1 & 0.863 & 0.745 & 0.724 & & 1.33039 & 1.967 \\
\hline Sumber: Data diolah, 2018 & & & & & &
\end{tabular}

Dari hasil output di atas menunjukkan besarnya nilai Adjusted $R^{2}$ adalah 0,724 atau $72,4 \%$ keragaman variabel disiplin kerja dapat dijelaskan oleh kombinasi variabel bebas gaya kepemimpinan, motivasi, komunikasi, dan budaya organisasional. Sedangkan sisanya $(100 \%-72,4 \%=27,6 \%)$ dijelaskan oleh variabel lain diluar model.

Tabel 9.

Hasil Uji Statistik F

\begin{tabular}{cccccc}
\hline Model & $\begin{array}{c}\text { Sum of } \\
\text { Square }\end{array}$ & Df & $\begin{array}{c}\text { Mean } \\
\text { Square }\end{array}$ & F & Sig. \\
\hline Regression & 248.251 & 4 & 62.063 & 35.065 & $.000^{\mathrm{b}}$ \\
Residual & 84.957 & 48 & 1.770 & & \\
Total & 333.208 & 52 & & & \\
\hline
\end{tabular}

Sumber: Data diolah, 2018

Berdasarkan hasil output di atas menunjukkan nilai signifikansi (Sig.) = $0,000<\alpha=0.05$, hal ini berarti $\mathrm{H}_{0}$ ditolak dan $\mathrm{H}_{1}$ diterima. Hal ini berarti variabel-variabel bebas yaitu Gaya Kepemimpinan, Motivasi, Komunikasi, dan 
Budaya Organisasional berpengaruh positif dan signifikan terhadap variabel terikatnya yaitu Disiplin Kerja.

Hasil uji t dapat dilihat pada tabel coefficients di kolom Sig. Jika signifikansi uji t atau $\operatorname{Sig}<\alpha=0.05$, maka dapat dikatakan bahwa terdapat pengaruh positif dan signifikan antara variabel bebas terhadap variabel terikat. Namun jika signifikansi uji t atau Sig $>\alpha=0.05$, maka dapat dikatakan bahwa tidak terdapat pengaruh positif dan signifikan antara masing-masing variabel bebas dan variabel terikat.

Tabel 10.

Hasil Uji Statistik t

\begin{tabular}{|c|c|c|c|c|}
\hline \multirow{2}{*}{ Variabel } & \multicolumn{2}{|c|}{ Standardized Coefficients } & \multirow[b]{2}{*}{$\mathbf{T}$} & \multirow{2}{*}{ Sig } \\
\hline & B & Std. Error & & \\
\hline (constant) & & 2.330 & -0.844 & 0.403 \\
\hline Gaya Kepemimpinan $\left(\mathrm{X}_{1}\right)$ & 0.466 & 0.070 & 4.280 & 0.000 \\
\hline Motivasi $\left(\mathrm{X}_{2}\right)$ & 0.234 & 0.146 & 2.728 & 0.009 \\
\hline Komunikasi $\left(\mathrm{X}_{3}\right)$ & 0.267 & 0.130 & 2.387 & 0.021 \\
\hline Budaya Organisasional $\left(\mathrm{X}_{4}\right)$ & 0.165 & 0.082 & 2.231 & 0.030 \\
\hline Dependent variable : disiplin kerja & & & & \\
\hline
\end{tabular}

Berdasarkan hasil pengujian secara parsial (uji t) menunjukkan nilai Sig. $=$ $0,000<\alpha=0.05$ sehingga dapat disimpulkan bahwa variabel bebas gaya kepemimpinan $\left(\mathrm{X}_{1}\right)$ berpengaruh positif dan signifikan terhadap variabel terikat disiplin kerja (Y). Hal ini berarti semakin baik gaya kepemimpinan yang diterapkan oleh instansi maka semakin tinggi pula disiplin kerja pegawai.

Berdasarkan hasil pengujian secara parsial (uji t) menunjukkan nilai Sig. $=$ $0,009<\alpha=0.05$ sehingga dapat disimpulkan bahwa variabel bebas motivasi $\left(\mathrm{X}_{2}\right)$ berpengaruh positif dan signifikan terhadap variabel terikat disiplin kerja (Y). Hal ini berarti semakin tinggi motivasi yang diberikan maka semakin tinggi pula disiplin kerja pegawai. 
Secara parsial (uji t) menunjukkan nilai Sig. $=0,021<\alpha=0.05$ sehingga dapat disimpulkan bahwa variabel bebas komunikasi $\left(\mathrm{X}_{3}\right)$ berpengaruh positif dan signifikan terhadap variabel terikat disiplin kerja (Y). Hal ini berarti semakin baik komunikasi maka semakin tinggi disiplin kerja pegawai.

Berdasarkan hasil pengujian secara parsial (uji t) menunjukkan nilai Sig. $=$ $0,030<\alpha=0.05$ sehingga dapat disimpulkan bahwa variabel bebas budaya organisasional $\left(\mathrm{X}_{4}\right)$ berpengaruh positif dan signifikan terhadap variabel terikat disiplin kerja (Y). Hal ini berarti semakin baik budaya organisasional yang diterapkan oleh instansi maka semakin tinggi disiplin kerja pegawai.

Tujuan penelitian ini adalah untuk mengetahui pengaruh gaya kepemimpinan terhadap disiplin kerja. Dari hasil perhitungan yang ditunjukan pada Tabel 10 dapat dijelaskan bahwa tingkat signifikansi $(0,000)$ lebih kecil dari $\alpha(0,05)$, sehingga $\mathrm{H}_{0}$ ditolak dan $\mathrm{H}_{1}$ diterima yang berarti bahwa gaya kepemimpinan $\left(\mathrm{X}_{1}\right)$ berpengaruh positif dan signifikan terhadap disiplin kerja pegawai kontrak Dinas Kebudayaan Provinsi Bali. Hasil penelitian ini mengembangkan hasil penelitian yang dilakukan oleh Mahdi et al. (2014), yang menyatakan bahwa kepemimpinan akan mampu meningkatkan tujuan organisasi dan untuk meningkatkan disiplin kerja pegawai. Hasil penelitian ini juga mengembangkan penelitian Ondari et al. (2016) yang menyatakan bahwa tingkat disiplin dipengaruhi oleh gaya kepemimpinan yang diterapkan oleh organisasi.

Tujuan penelitian ini adalah untuk mengetahui pengaruh motivasi terhadap disiplin kerja. Dari hasil perhitungan yang ditunjukan pada Tabel 10 dapat dijelaskan bahwa tingkat signifikansi $(0,009)$ lebih kecil dari $\alpha(0,05)$, sehingga 
$\mathrm{H}_{0}$ ditolak dan $\mathrm{H}_{2}$ diterima yang berarti bahwa motivasi $\left(\mathrm{X}_{2}\right)$ berpengaruh positif dan signifikan terhadap disiplin kerja pegawai kontrak Dinas Kebudayaan Provinsi Bali. Hasil penelitian ini mengembangkan hasil penelitian yang dilakukan olehChowdhury (2010), yang menyatakan bahwa motivasi merupakan faktor yang mempengaruhi disiplin karyawan. Hasil penelitian ini juga menyatakan bahwa Dessy dan Wibawa (2015), menyatakan bahwa motivasi berperan penting dalam meningkatkan disiplin kerja pegawai pada instansi.

Tujuan penelitian ini adalah untuk mengetahui pengaruh komunikasi terhadap disiplin kerja. Dari hasil perhitungan yang ditunjukan pada Tabel 10 dapat dijelaskan bahwa tingkat signifikansi $(0,021)$ lebih kecil dari $\alpha(0,05)$, sehingga $\mathrm{H}_{0}$ ditolak dan $\mathrm{H}_{3}$ diterima yang berarti bahwa komunikasi $\left(\mathrm{X}_{3}\right)$ berpengaruh positif dan signifikan terhadap disiplin kerja pegawai kontrak Dinas Kebudayaan Provinsi Bali. Hasil penelitian ini mengembangkan hasil penelitian yang dilakukan oleh Suaip dan Astuti (2015) yang menyatakan bahwa komunikasi berpengaruh signifikan terhadap disiplin kerja. Hal ini berarti semakin baik komunikasi dalam suatu instansi maka akan meningkatkan disiplin kerja pegawainya. Hasil penelitian ini juga mengembangkan penelitian yang dilakukan oleh Suniastuti dan Suana (2012) yang menyatakan bahwa motivasi berpengaruh positif terhadap disiplin kerja pegawai. Hal ini berarti semakin baik komunikasi yang diterapkan antara pimpinan dengan bawahan maupun antar sesama rekan sekerja maka akan semakin disiplin pula pegawai tersebut.

Tujuan penelitian ini adalah untuk mengetahui pengaruh budaya organisasional terhadap disiplin kerja. Dari hasil perhitungan yang ditunjukan 
pada Tabel 10 dapat dijelaskan bahwa tingkat signifikansi $(0,030)$ lebih kecil dari $\alpha(0,05)$, sehingga $\mathrm{H}_{0}$ ditolak dan $\mathrm{H}_{4}$ diterima yang berarti bahwa budaya organisasional $\left(\mathrm{X}_{4}\right)$ berpengaruh positif dan signifikan terhadap disiplin kerja pegawai kontrak Dinas Kebudayaan Provinsi Bali. Hasil penelitian ini mengembangkan hasil penelitian yang dilakukan oleh Oktaviani dan Saragih (2017) yang menyatakan bahwa budaya organisasional berpengaruh positif dan signifikan terhadap disiplin kerja karyawan, serta penelitian oleh Marhendro (2016) yang menyatakan bahwa budaya organisasi menjadi faktor yang mempengaruhi disiplin kerja pegawai yang berasal dari luar. Budaya organisasi yang kuat akan memaksa dan mempengaruhi anggotanya untuk melakukan sesuatu yang diperintahkan atau yang menjadi kebiasaan didalam organisasi tersebut.

Berdasarkan hasil penelitian yang telah dilakukan, terdapat beberapa implikasi yang dapat dihasilkan dengan adanya pembuatan penelitian ini. Implikasi teoritis penelitian ini adalah variabel gaya kepemimpinan, motivasi, komunikasi, dan budaya organisasional berpengaruh positif dan signifikan terhadap variabel disiplin kerja. Hasil penelitian ini memberi dukungan empiris dan dapat dinyatakan memperkuat hasil-hasil studi terdahulu.

Berdasarkan hasil penelitian ini dapat digunakan sebagai masukan bagi Kepala Dinas Kebudayaan Provinsi Bali dalam membenahi diri sehubungan dengan gaya kepemimpinan, motivasi, komunikasi, dan budaya organisasional agar dapat meningkatkan disiplin kerja pegawai kontrak Dinas Kebudayaan Provinsi Bali. 
Berdasarkan penelitian ini peneliti menggunakan kuesioner yang berupa pertanyaan-pertanyaan tertulis, sehingga kemungkinan responden tidak memahami pertanyaan dan asal menjawab. Selain itu, dalam penelitian ini peneliti hanya meneliti pegawai kontrak Dinas Kebudayaan Provinsi Bali, sehinga peneliti tidak dapat membandingkan hasil penelitian jika dilakukan pada Dinas lainnya.

\section{SIMPULAN DAN SARAN}

Terdapat pengaruh positif dan signifikan antara variabel gaya kepemimpinan $\left(\mathrm{X}_{1}\right)$ terhadap disiplin kerja (Y) pegawai kontrak Dinas Kebudayaan Provinsi Bali. Hal ini berarti semakin baik gaya kepemimpinan yang diterapkan pada Dinas Kebudayaan Provinsi Bali, maka semakin tinggi pula disiplin kerja pegawainya.

Terdapat pengaruh positif dan signifikan antara variabel motivasi $\left(\mathrm{X}_{2}\right)$ terhadap disiplin kerja (Y) pegawai kontrak Dinas Kebudayaan Provinsi Bali. Hal ini berarti semakin tinggi motivasi yang diberikan kepada pegawai, maka semakin tinggi pula disiplin kerja pegawai tersebut.

Terdapat pengaruh positif dan signifikan antara variabel komunikasi $\left(\mathrm{X}_{3}\right)$ terhadap disiplin kerja (Y) pegawai kontrak Dinas Kebudayaan Provinsi Bali. Hal ini berarti semakin baik komunikasi maka semakin tinggi pula disiplin kerja pegawainya.

Terdapat pengaruh positif dan signifikan antara variabel budaya organisasional $\left(\mathrm{X}_{4}\right)$ terhadap disiplin kerja (Y) pegawai kontrak Dinas Kebudayaan Provinsi Bali. Hal ini berarti semakin baik budaya organisasional 
yang diterapkan oleh Dinas Kebudayaan Provinsi Bali, maka semakin tinggi pula disiplin kerja pegawainya.

Saran secara teoritis untuk meningkatkan disiplin kerja, hal yang harus diperhatikan adalah gaya kepemimpinan, motivasi, komunikasi, dan budaya organisasional.

Saran secara teoritis lainnya yakni variabel budaya organisasional menjadi salah satu variabel yang sangat penting karena memiliki nilai standar koefisien paling rendah. Variabel yang harus diperhatikan dalam meningkatkan disiplin kerja adalah budaya organisasional dibandingkan dengan variabel gaya kepemimpinan, motivasi, dan komunikasi.

Saran secara praktis terhadap Dinas Kebudayaan Provinsi Bali untuk meningkatkan disiplin kerja dari pegawainya adalah dengan memperhatikan peran pimpinan (kepemimpinan untuk mempengaruhi orang lain agar orang tersebut bersedia secara ikhlas melaksanakan suatu pekerjaan dalam mencapai tujuan yang telah ditetapkan sebelumnya), motivasi (dorongan terhadap seorang untuk melakukan tindakan guna mencapai tujuan), komunikasi (proses penyampaian informasi dari seseorang kepada orang lain), serta budaya organisasional (budaya organisasi yang diterapkan dalam instansi). Karena hal tersebut dapat meningkatkan disiplin kerja dari pegawai itu sendiri.

Saran bagi penelitian selanjutnya, penelitian ini hanya sebatas meneliti mengenai gaya kepemimpinan, motivasi, komunikasi, dan budaya organisasional terhadap disiplin kerja. Peneliti selanjutnya diharapkan untuk menambah variabel lain, seperti: kepuasan kerja, pemberdayaan karyawan, kompensasi, dan 
komitmen organisasi, karena penelitian ini hanya memandang disiplin kerja pegawai yang dipengaruhi oleh gaya kepemimpinan, motivasi, komunikasi, dan budaya organisasional. Peneliti selanjutnya juga diharapkan untuk dapat menggunakan alat analisis lainnya serta mengambil sampel diluar lingkungan instansi pemerintah, seperti: industri perhotelan, UMKM, dan lembaga keuangan.

\section{REFERENSI}

Ardana, Komang., Ni Wayan Mujiati., dan I Wayan Mudiartha Utama. (2012). Manajemen Sumber Daya Manusia. Edisi Pertama. Yogyakarta: Graha Ilmu.

Azis, Ardiwan dan Bustari Muchtar. (2016). Pengaruh Komunikasi Organisasi dan Motivasi Kerja Terhadap Disiplin Kerja Pegawai pada Badan Kepegawaian Daerah (Bkd) Kota Bukittinggi. Jurnal Riset Manajemen Bisnis dan Publik. Universitas Negeri Padang.

Bangsawan, I Gusti Ngurah Bagus Putra. (2012). Analisis Faktor-Faktor yang Menentukan Disiplin Kerja Pegawai pada PT BPR Luhur Damai Tabanan. Skripsi. Denpasar: Universitas Udayana.

Beverly Alimo., John Alban., Jeevi Martissan., and Chara Samele. (2008). Impact of Engaging Leadership on Performance, Attitudes to Work and Wellbeing at Work. Journal of Health Organization and Management, 22 (6): 586-598.

Chowdhury, Mohammad. (2010). Some Factors in Increasing the Motivation to Employees Discipline. Journal of Business Management. Vol. 1(9).

Dessy, Putu Nika Adnya., dan I Made Artha Wibawa. (2015). Pengaruh Komunikasi, Motivasi Kerja, dan Pengalaman Kerja Terhadap Disiplin Pegawai PT. Bank Pembangunan Daerah Bali Kantor Pusat. Skripsi. Denpasar: Universitas Udayana.

Diantari, Ida Ayu Putu Septy., dan Ni Made Yuniari. (2014). Pengaruh Gaya Kepemimpinan, dan Motivasi Terhadap Disiplin Kerja Pegawai pada PT. Bank Tabungan Negara (Persero), Tbk. Cabang Denpasar. E-Jurnal Manajemen Universitas Udayana. Vol. 3 No. 5. pp. 1342-1360.

Damayanti, Dwitya dan Mahendra Fakhri. (2014). Pengaruh Budaya Organisasi Terhadap Disiplin Kerja Pegawai PT Angkasa Pura II (Persero) Kantor 
Cabang Utama Bandara Internasional Soekarno - Hatta Unit Personnel dan General Affairs. Jurnal Manajemen, 1 (3).

Flippo, Edwin B. (2001). Manajemen Personalia. Jakarta: Erlangga.

Hady, Hamdy., Bambang Sumali, Dudung Hadiwijaya, Mahfud, and Wawat Hermawati. (2017). Determinant of work discipline with organizational commitment as intervening variable. International Journal of Economic Research. Vol. 14 No. 17.

Iskandar. (2016). Implementasi Teori Hierarki Kebutuhan Abraham Maslow terhadap peningkatan kinerja pustakawan. Jurnal Ilmu Perpustakaan, Informasi, dan Kearsipan Khizanah Al-Hikmah. Vol. 4(1), 24-34.

Iswara, I Gusti Agung Rama Pramudita., dan I Nyoman Sudharma. (2013). Pengaruh Gaya Kepemimpinan, Budaya Organisasi, dan Lingkungan Kerja Fisik terhadap Disiplin Kerja Kayawan Dinas Pertanian Tanaman Pangan dan Hortikultura Kota Denpasar. Jurnal Manajemen, 2(6): 671682.

Jaya, Kadek Yudi Prawira., dan I Gusti Ayu Dewi Adnyani. (2015). Pengaruh Gaya Kepemimpinan terhadap Disiplin Kerja Pegawai di Dinas Balai Bahasa Provinsi Bali. Jurnal Manajemen, 4(9): 2702-2721.

Luthans. (2006). "Perilaku Organisasi". Edisi Kesepuluh. Yogyakarta: Andi.

Mahdi, Omar Rabeea, Erzan Shafizan Bin Gulam Mohd, and Mahmoud Khalid Almsafir. (2014). Empirical Study on the Impact of Leadership Behavior on Organizational Commitment in Plantation Companies in Malaysia. Journal of Business, Economics and Management, 109: 1076-1087.

Mohelska, H., and Sokolova, M. (2015). Organizational Culture and LeadershipJoint Vessels? Procedia: Social and Behavioral Sciences, 171: 10111016.

Oktaviani, Widya Dwi., dan Romat Saragih. (2017). Pengaruh Budaya Organisasi Terhadap Disiplin Kerja Karyawan Kantor Pusat Pt. Kereta Api Indonesia (Persero). e-Proceeding of Management : Vol.4, No.1.

Ondari, Enock O., Edward K. Tanui, dan Ruth Jepkemboi Choge. (2016). Influence of transformational leadership on discipline management and academic performance of student nurses in Kenya Medical Training Colleges in Kenya. IOSR Journal of Research and Method in Education (IOSR-JRME). Vol. 6 Issue 5 pp. 63-70. 
Permata, Sita Aulya., dan Ni Wayan Mujiati. (2017). Pengaruh Gaya Kepemimpinan dan Lingkungan Kerja Fisik Terhadap Disiplin Kerja Pegawai Disnakertrans Bali. Skripsi. Denpasar: Universitas Udayana.

Rahmadhani, Yuli. Dan Abubakar Iskandar. (2016). Analisis Pengaruh Komunikasi Organisasi Dan Budaya Organisasi Terhadap Disiplin Kerja Dan Implikasinya Terhadap Kinerja Pegawai Humas Dan Protokol Sekretariat Daerah Kabupaten Paser. Jurnal Komunikasi Pembangunan Institut Pertanian Bogor. Vol. 14 No. 2.

Rivai, Veithzal dan Sagala, Jauvani. (2009). Manajemen Sumber Daya Manusia untuk Instansi. Cetakan Ke 3. Jakarta: Rajawali Press.

Robbins, Stephen, P. (2010). Organizational Behavior, 15th Edition. New Jersey: Pearson Education, Inc.

Suaip, Muhammad Roni dan Hesti Widi Astuti. (2015). Pengaruh Komunikasi Terhadap Upaya Meningkatkan Disiplin Kerja Pegawai PT. Jamsostek (Persero) Bandar Lampung. Jurnal Bisnis Darmajaya. Vol. 1, No. 1.

Suniastuti, Ni Putu Ester., dan I Wayan Suana. (2012). Pengaruh Gaya Kepemimpinan, Budaya Organisasi, dan Komunikasi terhadap Disiplin Kerja Pegawai Instansi Daerah Parkir Kota Denpasar. Jurnal Manajemen, 1(1): 90-109.

Sugiyatmi, Susanty Aries., dan Sigit Wahyu Baskoro. (2012). Pengaruh Motivasi Kerja dan Gaya Kepemimpinan terhadap Disiplin Kerja serta Dampaknya pada Kinerja Pegawai (Studi Kasus pada PT. PLN (Persero) APD Semarang). Jurnal Teknik Industri, 7(2).

Sutrisno, Edy. (2009). Manajemen Sumber Daya Manusia. Jakarta: Kencana Prenada Media Group. 